\title{
Changes in $\gamma$-aminobutyric acid concentration, gas exchange, and leaf anatomy in Eucalyptus clones under drought stress and rewatering
}

\author{
Marina Shinkai Gentil Otto $^{1}$ (D) Jeane Gisele Francisco ${ }^{1,2} \cdot$ Beatriz Teixeira Gonsalez $^{1}$. \\ Lara de Almeida Calvo ${ }^{1}$ Eduardo Moré de Mattos $^{1,3} \cdot$ Marcílio de Almeida $^{1}$. \\ Rafael de Andrade Moral ${ }^{1}$ Clarice Garcia Borges Demétrio ${ }^{1} \cdot$ José Luiz Stape $^{1,4}$. \\ Ricardo Ferraz de Oliveira ${ }^{1}$
}

Received: 26 July 2016/Revised: 7 April 2017/Accepted: 18 August 2017/Published online: 28 August 2017

(C) Franciszek Górski Institute of Plant Physiology, Polish Academy of Sciences, Kraków 2017

\begin{abstract}
Drought stress promotes biochemical and physiological alterations in plant metabolism that limit growth and yield. This study investigated the accumulation of $\gamma$ aminobutyric acid (GABA) in plant tissue, the stomatal conductance (gs) and changes in leaf anatomy in Eucalyptus following drought stress situation. In this study, eight $E u$ calyptus clones were evaluated under normal water supply (control) and drought stress conditions (stress). For the control treatment, plants were irrigated every day with an automated system until the soil was saturated, and for the stress treatment, drought stress was imposed by non-irrigation of plants, and pots were covered using plastic sheeting to avoid rainfall and humidity. This study has shown that: (1) all clones decreased gs with increasing vapor pressure
\end{abstract}

Communicated by L. Bavaresco.

Marina Shinkai Gentil Otto

msgentil@usp.br

Jeane Gisele Francisco

jeane.quimica@gmail.com

Beatriz Teixeira Gonsalez

beatriz.gonsalez@usp.br

Lara de Almeida Calvo

laracalvo1@gmail.com

Eduardo Moré de Mattos

eduardo@4tree.com.br

Marcílio de Almeida

malmeida@usp.br

Rafael de Andrade Moral

rafael.moral@usp.br

Clarice Garcia Borges Demétrio

clarice.demetrio@usp.br deficit $(D)$ in both treatments. All plastics and drought-tolerant clones (except GG) presented lower stomatal sensitivity to $D$ under stress conditions than drought-sensitive clones; (2) GABA concentrations increased fast after drought stress, but we could not find correlation with these changes and resistance to water stress; and (3) all clones increased the number of stomata and reduced leaf thickness after water stress. The finding is that GABA is a fast stresssignaling molecule in Eucalyptus, but the response of gs to $D$ is a best physiological variable to differentiate droughttolerant and drought-sensitive Eucalyptus clones.

Keywords GABA - Stomatal conductance - Water stress · Recovery

José Luiz Stape

stape@suzano.com.br

Ricardo Ferraz de Oliveira

rfo@usp.br

1 Department of Plant Physiology and Biochemistry,

University of Sao Paulo, Av. Padua Dias 11, Piracicaba, SP 13418-970, Brazil

2 Center for Nuclear Energy in Agriculture, University of Sao Paulo, Av. Centenário, 303, Piracicaba 13418-970, Brazil

3 4Tree Agroflorestal Company, R. Tiradentes435, Piracicaba, SP 13400-760, Brazil

4 Suzano Papel e Celulose, Rod. Br 101, km 945,5, s/n, Mucuri, BA 45930-000, Brazil 


\section{Introduction}

Understanding the interaction between plant physiology and environment allows defining management strategies to alleviate stress conditions in agricultural or forestry species, as well as to select drought-tolerant genotypes in breeding programs. Different physiological responses occur once plants have a perception system composed of a network of molecules with the capability of transferring and processing information about environmental changes (Roshchina 2001). Despite major progress in understanding how water stress affects plant function (Sperry et al. 1998; Breda et al. 2006; Flexas et al. 2009), plant perception of climatic variations remains poorly resolved, and this limits our ability to adequately predict drought tolerance-related variables under stress conditions.

Several studies have identified substances in plants that are also found in the nervous systems of animals, such as histamine (Barger and Dale 1910), acetylcholine (Ewis 1914), dopamine (Buelow and Gisvold 1944), adrenaline (Askar et al. 1972), and serotonin (Bowden et al. 1954). The presence of $\gamma$-aminobutyric acid (GABA) in plants was first discovered in 1949 in potato tuber (Steward et al. 1949). GABA is a nonprotein amino acid that occurs in high levels in the brain of animals as a neurotransmitter (Steward et al. 1949).

Interest in GABA metabolism in plants has increased following experimental observations that GABA is rapidly produced in response to biotic and abiotic stresses (Kinnersley and Turano 2000; Warren et al. 2011). These situations have been reported in drought-stressed cotton (Hanower and Brzozowska 1975), in beans (Raggi 1994), in turnips (Thompson et al. 1996), in Eucalyptus (Warren et al. 2011, 2012a, b), in heat-stressed cowpea cells (Mayer et al. 1990), in cold-stressed soybeans (Wallace et al. 1984), tomato (Snowden et al. 2015), banana (Wang et al. 2014), pear fruit (Yu et al. 2014), and in strawberries subjected to high $\mathrm{CO}_{2}$ concentration (Deewatthanawong et al. 2010). Furthermore, Bown et al. (2002) demonstrated that when tobacco insect larvae simply walk on soybean plants, a stimulation of GABA synthesis occurs in minutes, indicating that GABA is a stress-signaling molecule.

GABA metabolism has been associated with many physiological responses, including the regulation of cytosolic $\mathrm{pH}$ (Carroll et al. 1994; Snedden et al. 1995; Mazzucotelli et al. 2006), nitrogen metabolism (Rolin et al. 2000; Buve et al. 2004), biotic defense (MC Lean et al. 2003; Mac Gregor et al. 2003, Scholz et al. 2015), protection against oxidative stress (Bouché et al. 2003; Fait et al. 2006), osmoregulation (Schawacke et al. 1999; Shelp et al. 1999), signaling (Bouché and Fromm 2004; Michaeli and Fromm 2015), regulation of pollen tube, and root growth (Ramesh et al. 2015). A recent study investigated that the response of the GABA-depleted gad1/2 mutant to drought stress and their findings suggests that GABA accumulation during drought is a stress-specific response and its accumulation induces the regulation of stomatal opening thereby prevents loss of water (Mekonnen et al. 2016).

The limitation of plant growth imposed by water stress is mainly due to a reduction in photosynthesis. For this reason, photosynthetic response to drought has been subject of studies and debate for decades (Lawlor and Cornig 2002). There are many studies from gas exchange to water stress that show that stomatal control is an important mechanism for plant survival under stress conditions, and different species may exhibit different stomatal sensitivity to vapor pressure deficit $(D)$ (Oren et al. 1999; Mediavilla and Escudeiro 2004; Addington et al. 2004; Huaman 2010; Mokotedi 2013; Eksteen et al. 2013; Ocheltree et al. 2013). Species and individuals that exhibit high gs at a low $D$ tend to have greater stomatal sensitivity to an increasing $D$ (Oren et al. 1999; Addington et al. 2004; Maherali et al. 2006).

The effects of water stress on photosynthesis have been intensively studied, but the recovery of photosynthesis following drought has been studied less intensively. Even though there are many studies showing different concentrations of GABA in response to drought and differences in the response of stomatal conductance in water-stress situations, there are few studies that examine these physiological variables under water-stress conditions simultaneously. To understand how plants are affected by water status, we need to examine simultaneously the multiple effects of water stress on stomatal changes, internal conductance, and leaf metabolites (Warren et al. 2011).

Differences in morphological and anatomical parameters of leaves are important to understanding the mechanisms related to plants living in water-stressed conditions. Stomatal control and stomatal density are important factors determining water relationships and their relationship to photosynthesis and GABA accumulation is poorly understood. This is important, since one way for plants to adjust to environmental conditions is to modify their leaf anatomy (Cutler et al. 2011). Such modification includes changes in palisade layers, spongy layers, and intercellular space in plants living in water shortage conditions (Chartzoulakis et al. 2002).

Eucalyptus is an important species that accounts for $8 \%$ of planted forests in the world (FAO 2011). With the expansion of Eucalyptus planted in regions under water stress, it becomes necessary to increase our understanding of physiological and anatomical processes triggered by plants under water-stress conditions. Development of varieties exhibiting increased drought tolerance for any 
plant species would result in a more stable yield under stress conditions (Eksteen et al. 2013). However, breeding, specifically for drought tolerance, is still time-consuming and expensive (Pidgeon et al. 2006). The distinction between drought-tolerant clones and drought-sensitive clones is particularly relevant to assisting Eucalyptus breeding programs for selecting clones that are more productive under water-stress situations.

We hypothesized that GABA is an early indicator of water-stress situation and that drought-tolerant and sensitive Eucalyptus clones differ in physiological and anatomical parameters following water-stress situation. To provide an integrated picture of how plants responds to drought stress and recovery, this study examines responses of physiology variables (water potential, stomatal control in response to water pressure deficit- $D$ ), GABA concentration, and leaf anatomy in eight Eucalyptus clones from dry and humid regions of Brazil.

\section{Materials and methods}

\section{Plant material and experimental design}

Cuttings of eight Eucalyptus clones from different geographical and climatological breeds were evaluated in this study. Clones planted in humid regions were considered drought-sensitive to water stress, clones planted in dry regions were considered drought-tolerant, and clones planted in both (dry and humid regions) were considered plastics (Table 1). These clones were planted in $320 \mathrm{~L}$ pots containing $66 \%$ soil, $17 \%$ sand, and $17 \%$ peat in February 2013. Two plants were planted in each pot.

The study was carried out in Piracicaba, São Paulo, Brazil $\left(22^{\circ} 42^{\prime} 30^{\prime \prime} \mathrm{S}, 47^{\circ} 38^{\prime} 00^{\prime \prime} \mathrm{W}\right)$. Piracicaba has an average annual temperature of $21.6^{\circ} \mathrm{C}$, average precipitation of $1230 \mathrm{~mm} \mathrm{year}^{-1}$, and average potential evapotranspiration of $1042 \mathrm{~mm}$ year $^{-1}$. The site's climate is classified as Cfa (humid temperate) under the Koppen Classification (Alvares et al. 2013) and consists of three winter months (June, July, and August), a dry season during the winter and a wet season during the summer. Total rainfall for the study period (October 2013-January 2014) was $684 \mathrm{~mm}$, and the monthly average temperature was $25^{\circ} \mathrm{C}$.

It was adopted a completely randomized experimental design, in a factorial scheme $2 \times 8$ : two treatments (drought stress-stress; and normal water supply-control) and eight Eucalyptus clones, with six replicates, totaling 96 experimental units. For the normal water supply treatment, plants were irrigated every day with an automated system until the soil was saturated. Plants of both treatments received similar water supply in the first 9 months. Drought stress treatment began on November 12th when plants were 9 months and $10-15 \mathrm{~m}$ tall. Water stress was imposed by non-irrigation of the plants, and the pots were covered using plastic sheeting to avoid rainfall and humidity. Water was withheld in three cycles: two waterstress days (cycle 1), four water-stress days (cycle 2), and two water-stress days (cycle 3 ). Between cycle 1 and cycle 2 , water-stressed plants were rehydrated for 2 weeks, so they could completely recover.

\section{Leaf water potential}

Leaf water potential ( $\left.\Psi_{\text {leaf }}\right)$ was determined during drought stress days (T1 and T2; T15-T18; and T41 and T42) and after recovery watering ( $\mathrm{R} 1 \mathrm{~d}, \mathrm{R} 2 \mathrm{~d}$, and $\mathrm{R} 3 \mathrm{~d}$; $\mathrm{R} 22 \mathrm{~d}, \mathrm{R} 28 \mathrm{~d}$, and R30d). We measured four fully expanded leaves for each treatment, located in the middle of the tree crown, at midday (11-12 am) and predawn (4-5 am) during the drought cycle using a Scholander chamber (1965).

\section{GABA analysis}

\section{Extraction and quantification}

Leaf samples were collected on the same days that we measured water potential. All leaves were collected on the same time and between noon and $1 \mathrm{pm}$ on sunlit days when water stress is most severe and to control possible diurnal variations in GABA concentration. We punched three leaves of four plants per treatment (12 repetitions) from the middle part of the crown, and they were immediately frozen in liquid $\mathrm{N}$ and subsequently stored at $-80{ }^{\circ} \mathrm{C}$.

GABA concentration was extracted using mixture of methanol, chloroform, and water (12:5:3, v:v) according to the method described by De diego et al. (2012).

For the quantification, analyses were carried out on an LC-ESI-MS/MS system, a Liquid Agilent (Wilmington, DE, USA) Chromatograph 1200. The chromatographic separations were carried out using a Thermo Scientific Hypersil GOLD C18 column $(100 \mathrm{~mm} \times 2.1 \mathrm{~mm}, 3 \mu \mathrm{m}$ particle size). Table 2 shows the chromatographic parameters used for GABA detection.

The mobile phases were (A) $0.1 \%$ formic acid in Milli$\mathrm{Q}^{\circledR}$ water (Millipore; Bedford, USA) and (B) $0.1 \%$ formic acid in acetonitrile. The elution was in isocratic mode with the proportion of A:B being 20:80, v/v. The flow remained constant at $0.40 \mathrm{~mL} \mathrm{~min}{ }^{-1}$, the column temperature was fixed at $30{ }^{\circ} \mathrm{C}$, and the injection volume was $5 \mu \mathrm{L}$.

We used a Quadruple Triple 6430 mass spectrometer as a detector. The ESI parameters in the positive ionization mode were: gas flow of $10 \mathrm{~L} / \mathrm{min}$, gas nebulizer at $50 \mathrm{psi}$, gas temperature at $350{ }^{\circ} \mathrm{C}$, and capillary voltage of $4000 \mathrm{~V}$. Nitrogen $99.99 \%$ was used as a nebulizer and 99.9999\% as a collision gas. We used the Agilent Mass 
Table 1 Origin of the eight Eucalyptus clones (map modified from Alvares et al. 2013)

\begin{tabular}{ccc}
\hline Clone & Hibrid/Specie & $\begin{array}{c}\text { Water stress } \\
\text { Classification }\end{array}$ \\
\hline CNB & E. urophylla $x$ E. grandis & Sensitive \\
FIB & E. urophylla $x$ E. grandis & Sensitive \\
JAR & E. urophylla $x$ E. grandis & Sensitive \\
GG & E.urophylla & Tolerant \\
SUZ & E. urophylla $x$ E. tereticornis & Tolerant \\
VM & E. urophylla & Tolerant \\
VER & E. urophylla & Plastic \\
COP & E. grandis $x$ E. camaldulensis & Plastic \\
\hline
\end{tabular}

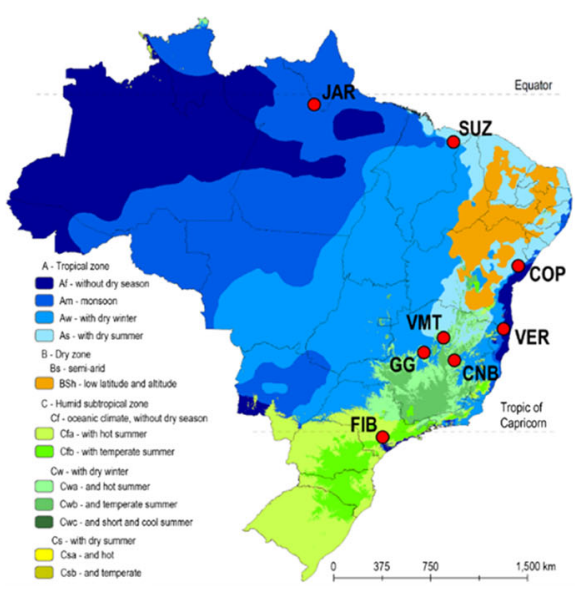

Table 2 Detection and chromatographic parameters

\begin{tabular}{llc}
\hline Transitions & Fragmentation energy (V) & Collision energy (V) \\
\hline $104.1->87.2^{\mathrm{a}}$ & 45 & 4 \\
$104.1->69.2^{\mathrm{b}}$ & 45 & 12 \\
\hline
\end{tabular}

a Quantifier

${ }^{\mathrm{b}}$ Qualifier

Hunter software for data acquisition, and we used the MRM mode for detection in the MS/MS.

\section{Leaf gas-exchange measurements}

We evaluated gas-exchange variables using the LI-6400 system (Li-Cor, Lincoln, NE, USA) on every day that we measured the water potential and GABA concentration. Measurements were performed after 10-15 min of stabilization in a light saturation of $1500 \mu \mathrm{mol} \mathrm{m} \mathrm{m}^{-2} \mathrm{~s}^{-1}$, ambient humidity greater than $50 \%$, and $\mathrm{CO}_{2}$ concentration of $400 \mathrm{ppm}$. We measured nine repetitions per treatment on fully expanded leaves located in the middle of the tree crown. To observe variations between stomatal conductance and $D$, measurements were taken in the morning (8-12 am) and afternoon (2-5 pm).

\section{Stomatal anatomy}

Samples of fully expanded leaves, chosen at random from the middle third portion of shoots, were collected from each clone on two dates: (1) before water-stress days (T1) and (2) after all water-stress cycles (T42). To capture the water-stress effect, newly emergent leaves were tagged in the upper third of the crown after cycle 1 and collected after three water-stress cycles when they were fully expanded (Fig. 1).

Leaf spring samples of two sides were taken on three leaves for each clone by the superglue technique adapted from Gulcan and Misirli (1990). This sampling was performed on the middle portion of the leaf because previous studies showed that the highest stomatal frequency is found near the leaf tip, the lowest frequency near the leaf base, and an intermediate frequency in the middle (Salisbury 1927; Miranda et al. 1981).

Stomatal frequency was studied for 3072 fields [8 clones $\times 3$ leaves $\times 2$ leaf sides (abaxial and adaxial) $\times 4$ slides $\times 4$ fields $\times 2$ treatments $\times 2$ periods] chosen at random in the middle of the blade. Stomatal quantity was measured under an optical microscope, and the stomata were manually counted on digital images for each field. Approximately 27,195 stomata were counted in total. From these measurements, mean stomatal frequency was determined for each leaf surface for each replicate. Stomatal frequency was calculated as the number of stomata/ $/ \mathrm{mm}^{2}$ (n. $\mathrm{mm}^{-2}$ ).

\section{Statistical methodology}

Generalized additive models (Wood 2006) were fitted to the stomatal conductance data including different smoothing functions with a cubic spline basis over $D$ for each treatment (different linear predictors). Sub-models were also fitted, i.e., parallel and coincident linear predictors and tested using likelihood-ratio tests. Then, the same models were fitted to these data split for each clone. Generalized additive models were also fitted to the GABA data including a smoothing function with a cubic spline basis over water potential. 


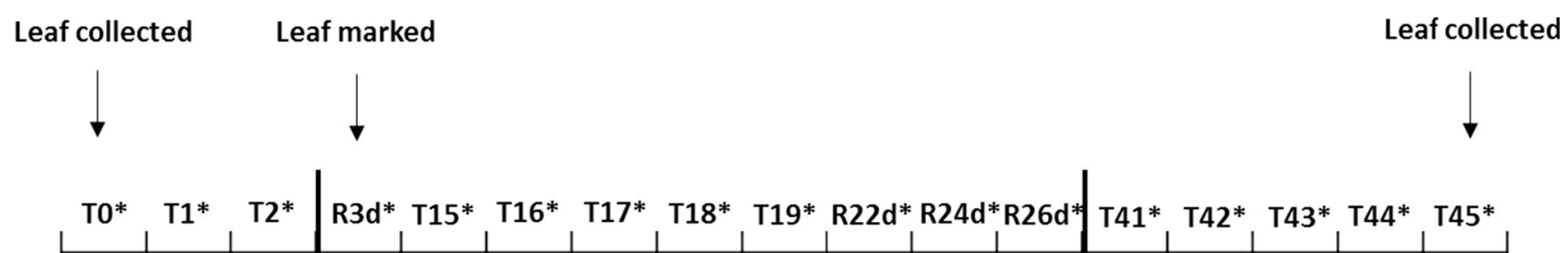

Cycle 1

Fig. 1 Water-stress cycles. T1 and T2, T15-T19, and T41 and T42 are days with water stress, and R3d and R22d-R26d are watering days. The asterisks represent days with stomatal conductance and

For comparison of GABA concentration under water stress and after rehydrating, multiple comparisons were performed using Tukey's test $(p=0.05)$.

Analysis of variance models were fitted to the continuous variables associated with leaf anatomy, including the effects of clone, treatment, and the interaction between clone and treatment in the linear predictor. Multiple comparisons were made using Tukey's test $(p=0.05)$. All analyses were carried out using the statistical software R ( R Core Team 2014).

\section{Results}

\section{Plant water status}

During the control treatment, the $\Psi_{\text {pd }}$ average was $-0.2 \mathrm{MPa}$, with few variations during the entire period, and ranged from -0.06 to $-1.2 \mathrm{MPa}$, suggesting that water availability for control treatment was adequate for all clones during the study period. The lowest $\Psi_{\mathrm{pd}}$ in this treatment occurred on November 29th (T16) and 30th (T17), which were the hottest days during the entire period, with 29 and $28.7^{\circ} \mathrm{C}$ as average temperatures, respectively. Measured values of $\Psi_{\mathrm{pd}}$ during good water supply were in agreement with the values reported by Mielke et al. (1998) for Eucalyptus grandis plantation in Espirito Santo, Brazil, and Dye (1996) in South Africa.

Changes in water potential are illustrated in Fig. 2. Values of $\Psi_{\mathrm{pd}}$ during stress treatment ranged from -0.6 to $-2.7 \mathrm{MPa}$, with the minimum values occurring on day T41 when the maximum temperature reached $34{ }^{\circ} \mathrm{C}$ at noon, DPV was $3.2 \mathrm{kPa}$, and relative humidity was $41 \%$.

During stress days, the values of $\Psi_{\mathrm{pd}}$ for all clones were around $-1.5 \mathrm{MPa}$, with the lowest value of $\Psi_{\text {pd }}$ occurring during days with maximum water stress for each cycle, i.e., T2 (cycle 1), T18 (cycle 2), and T44 (cycle 3). On those days, the predawn leaf water potential ranged from -2.3 to $-3.6 \mathrm{MPa}$, and 1 day after rehydration, all clones recovered and increased $\Psi_{\mathrm{pd}}$, to values of -0.05 to $-0.6 \mathrm{MPa}$. For the midday water potential $\left(\Psi_{\mathrm{md}}\right)$, water-stressed plants water potential measurements, and arrows indicate days when leaves were collected and marked for anatomical evaluations

exhibited $-1.8 \mathrm{MPa}$ (ranging from -0.7 to $-3 \mathrm{MPa}$ ), and exhibited -0.4 to $-2 \mathrm{MPa}$ after rewatering.

In the first cycle, all clones increased $\Psi_{\mathrm{pd}}$ and $\Psi_{\mathrm{md}}$ 1 day after rehydration, matching the values of $\Psi_{\mathrm{pd}}$ and $\Psi_{\text {md }}$ of the control treatment samples. The recovery of $\Psi_{\mathrm{pd}}$ in the second cycle also occurred 1 day after rewatering, but $\Psi_{\text {md }}$ increased 2 days after rewatering, showing that water stress in the second cycle caused more damage to all clones, which needed 2 days to recover $\Psi_{\mathrm{md}}$ completely.

\section{Responses of gas exchange to water stress}

Stomatal conductance decreased with increased vapor pressure deficit during both treatments. One of the most significant environmental variables controlling gs is the $D$, which is a stomatal response that prevents excessive dehydration and hydraulic failure (Schulze et al. 1982; Mott and Parkhurst 1991; Oren et al. 1999).

Increased stomatal sensitivity to $D$ is an indication of isohydric behavior, i.e., stomata limit transpiration once $D$ is increased to prevent the leaf water potential from decreasing to levels that endanger the hydraulic system integrity (Gharun et al. 2015).

Moreover, the likelihood-ratio test between the different linear prediction model vs the parallel linear predictor model was significant $\left(\chi_{1.6}^{2}=21.27, p<0.0001\right)$, the stomatal conductance decreased with increasing $D$ for both treatments (stress and control), but the equation for relationships was different comparing both treatments (Fig. 3).

During the stress treatment, the relationship between stomatal conductance and $D$ was lower than during control treatment, showing that, in this case, in addition to $D$, water restriction in the soil also contributed to stomatal closure. Plants in more drought-prone environments generally show lower minimum stomatal conductance (Christman et al. 2008).

Comparing all clones, we can define different allometric equations for relationships between gs and $D$ for each clone (Table 3). For instance, drought-sensitive clones (CNB, FIB, and JAR) yielded parallel curves between stress and 

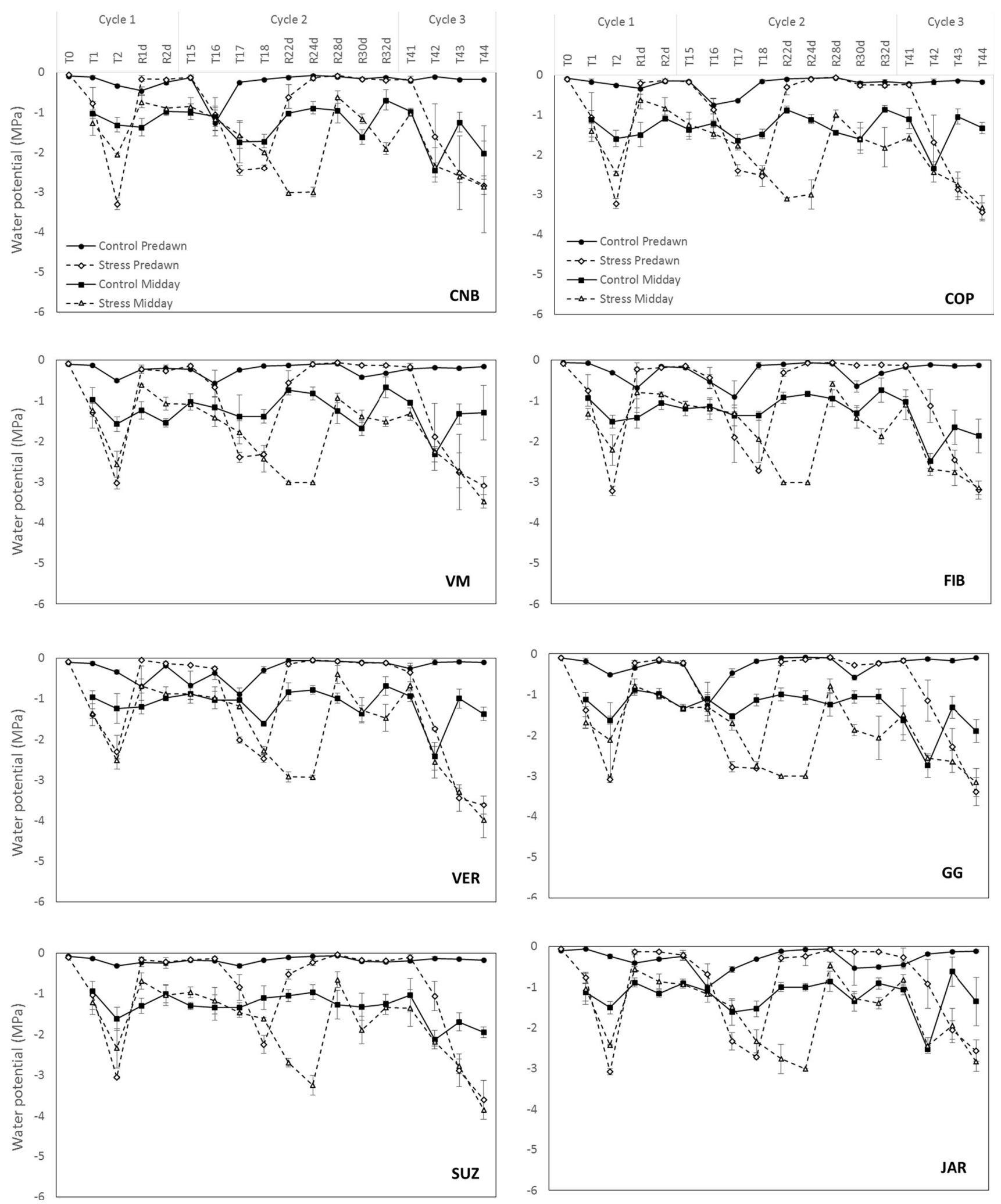

Fig. 2 Leaf water potential in eight Eucalyptus clones exposed to water stress during a drought period (T0-T45) with subsequent recovery after rewatering (R1d-R32d) and control treatment 


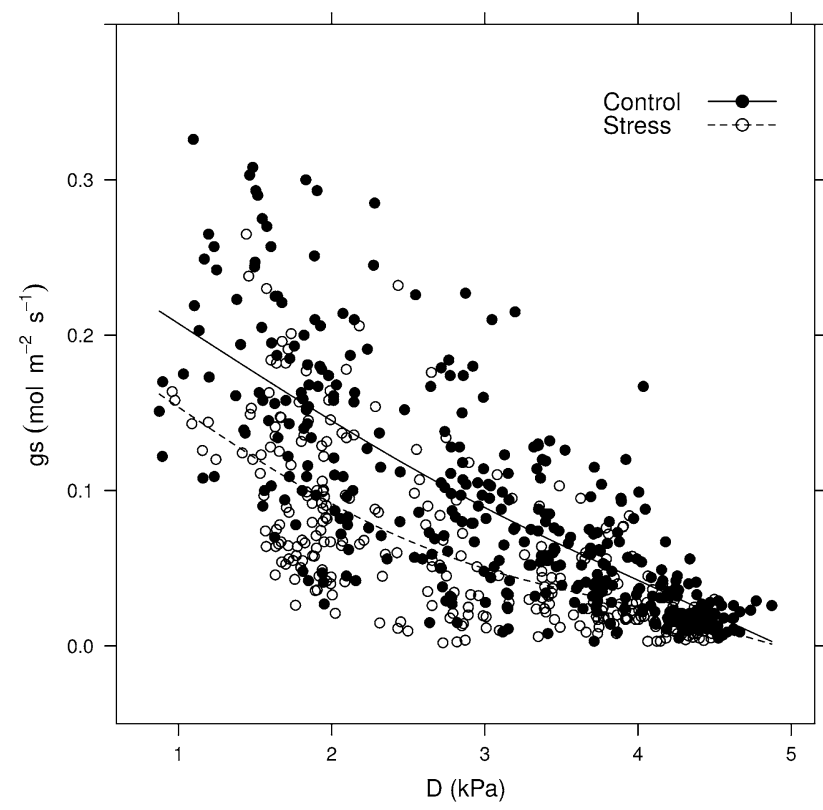

Fig. 3 Relationship between stomatal conductance (gs) and $D$ in plants subjected to stress (white circles) and control (black circles) treatments

Table 3 Likelihood-ratio tests for the generalized additive models fitted to the gs data for each Eucalyptus clone

\begin{tabular}{lll}
\hline Clone & Test \\
\cline { 2 - 3 } & Different vs. parallel & Parallel vs. coincident \\
\hline CNB & $\chi_{2.7}^{2}=1.49, p=0.6275$ & $\chi_{1.1}^{2}=14.03, p=0.0002$ \\
COP & $\chi_{1.5}^{2}=14.81, p=0.0003$ & - \\
FIB & $\chi_{1.3}^{2}=1.30, p=0.1586$ & $\chi_{1.1}^{2}=17.02, p<0.0001$ \\
GG & $\chi_{3.0}^{2}=5.47, p=0.1427$ & $\chi_{1.0}^{2}=0.95, p=0.3170$ \\
JAR & $\chi_{1.2}^{2}=2.69, p=0.1310$ & $\chi_{1.3}^{2}=11.75, p=0.0010$ \\
SUZ & $\chi_{1.4}^{2}=18.75, p<0.0001$ & - \\
VER & $\chi_{1.8}^{2}=10.49, p=0.0041$ & - \\
VM & $\chi_{2.5}^{2}=11.76, p=0.0050$ & - \\
\hline
\end{tabular}

control treatments. This means that the stomatal sensitivity to $D$ was the same between treatments, but during the stress treatment, stomata were more closed than during the control treatment, a clear effect of water stress. Even though these clones revealed parallel curves, they had different behaviors when compared. For example, FIB exhibited a continuous curve in both treatments, but $\mathrm{CNB}$ and JAR clones exhibited curves with a lower slope after approximately $3.0 \mathrm{kPa}$ of $D$ in both treatments (Table 3 ).

Drought-tolerant clones (SUZ, VM, except GG) and plastic clones (VER and COP) exhibited concurrent curves; hence, stress and control treatments exhibited different behaviors. In the control treatment, SUZ and VM exhibited

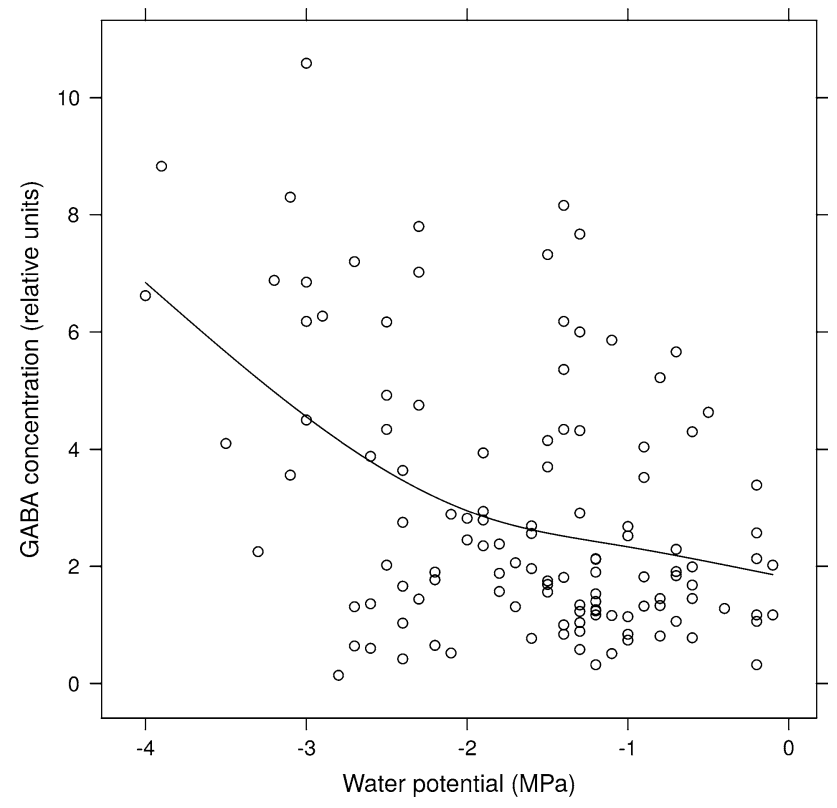

Fig. 4 Relationship between GABA concentration and midday water potential

higher gs values until $\sim 2.0 \mathrm{kPa}$, after which they exhibited a reduced curve slope. In the stress treatment, the curve slope was lower than in the control treatment and was uniform for variations of $D$. GG was the only clone that exhibited coinciding curves; therefore, this clone showed no difference in its gs and $D$ relationship when comparing both treatments (Table 3).

In contrast to SUZ and VM, plastic clones (COP and VER) in the control treatment had a lower slope at the beginning of the curve and a higher slope after $2.5 \mathrm{kPa}$ of $D$. In the stress treatment, stomatal conductance was lower compared with the control treatment, and the curve slope was lower and uniform for all values of $D$, similar to SUZ and VM.

\section{GABA concentration}

Water-stressed plants exhibited increased GABA concentration during days with the lowest midday leaf water potential (Fig. 4).

Clones exhibited more GABA on the second stress day (T2) of cycle 1, except COP and GG, which showed a higher concentration on the first day (T1). During cycle 2, all clones exhibited a higher concentration on the fourth stress day. During cycle 3, all clones exhibited concentrated GABA on the second stress day (T42), except JAR, which showed a lower GABA concentration (0.07) (Fig. 5).

Water stress decreased photosynthesis and water potential; in addition, GABA levels were quantitatively 

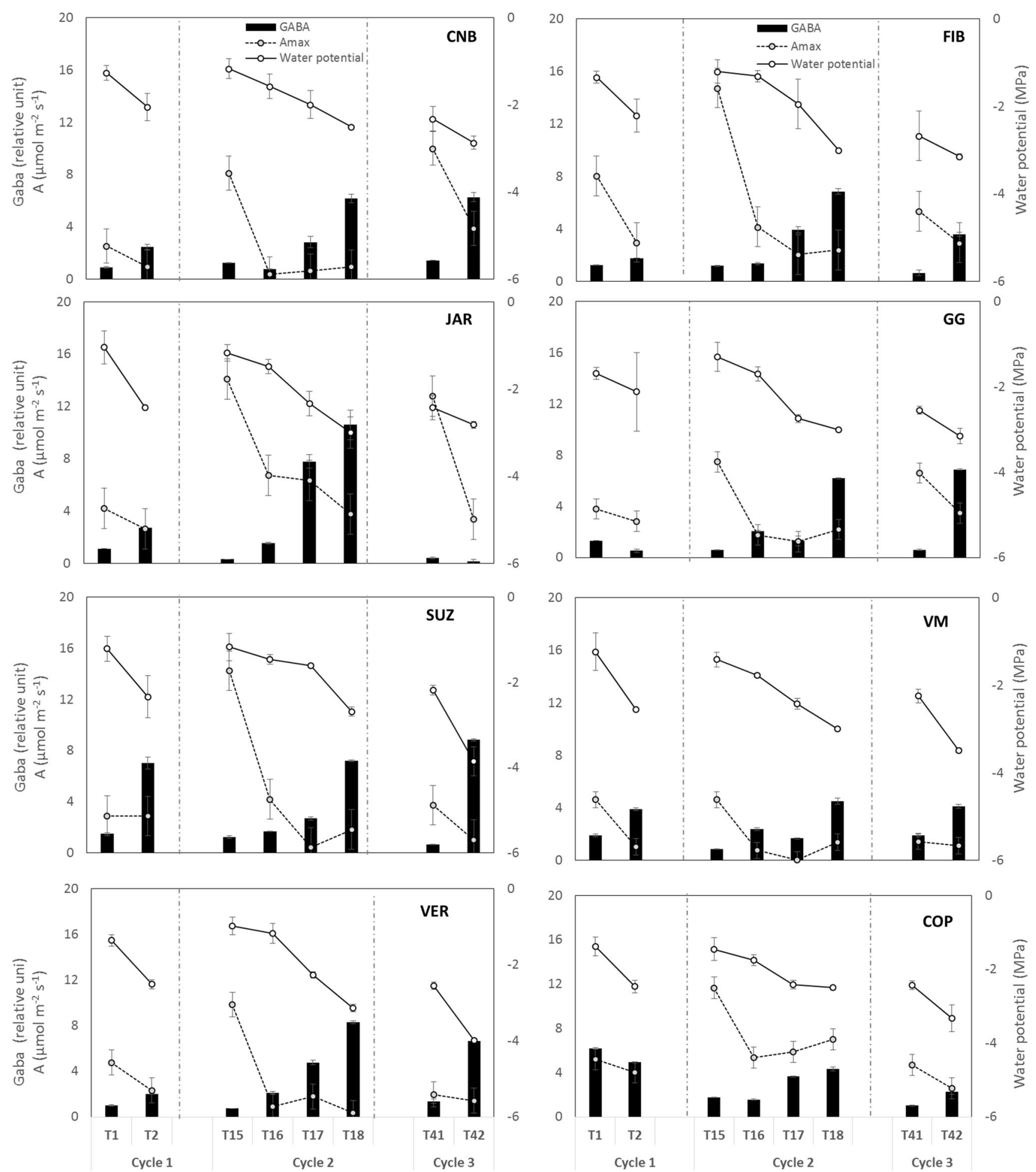

Fig. 5 Variations in water potential, photosynthesis (a) and the GABA relationship in three cycles of water-stressed days for eight Eucalyptus clones. Error bars indicate standard deviation for $n=4$

significant and changed by a factor of 0.1-10.6 after water stress of Eucalyptus clones (Fig. 5).

There was a significant difference in the GABA concentration of all clones on water-stress days, but there was no relationship between these differences and tolerance to water stress (Table 4). This lack of correlation between GABA and tolerance to water stress does not support the hypothesis that GABA is associated with tolerance. In this 
Table 4 GABA concentration of eight Eucalyptus clones during water-stress days and after rewatering

\begin{tabular}{lll}
\hline Clone & \multicolumn{2}{l}{ GABA (relative units) } \\
\cline { 2 - 3 } & Stress $(\%)$ & Rewatering $(\%)$ \\
\hline GG & $2.05 \mathrm{aA}$ & $1.36 \mathrm{aA}$ \\
CNB & $2.53 \mathrm{aA}$ & $1.12 \mathrm{aB}$ \\
VER & $2.93 \mathrm{abA}$ & $1.66 \mathrm{aA}$ \\
COP & $3.72 \mathrm{abcA}$ & $1.18 \mathrm{aB}$ \\
JAR & $4.19 \mathrm{abcA}$ & $1.52 \mathrm{aB}$ \\
SUZ & $4.39 \mathrm{bcA}$ & $1.85 \mathrm{aB}$ \\
VM & $4.94 \mathrm{cA}$ & $2.58 \mathrm{aB}$ \\
FIB & $6.37 \mathrm{dA}$ & $0.95 \mathrm{aB}$ \\
$\mathrm{P}<$ & 0.3305 & \\
DMS & 2.2514 & \\
CV $(\%)$ & 0.5213 & \\
\hline
\end{tabular}

* Lowercase letters indicate differences in the column and capital letters indicate differences in the row $(p=0.05)$

study, we determined GABA content in plant leaves; however, the clones studied exhibited different leaf quantities in their canopy and exhibited a specific dynamic leaf area index; therefore, the total amount of GABA in the crown may vary for each clone, which was not included in this work.

In all clones except GG and VER, water stress led to reversible changes in GABA levels. After rehydrating, GABA was rapidly reduced (Table 4); this occurrence was also observed by Warren et al. (2011). Shelp et al. (2012) suggested that GABA may, in turn, be used to rapidly generate succinate and energy via the tricarboxylic acid cycle upon stress removal.

\section{Anatomical changes after water stress}

There was a significant reduction of leaf thickness (LT) and an increase of abaxial stomatal density (AbD) in all clones after water stress (Table 5). All clones increased their number of stomata after water stress (Table 5; Fig. 6). The stress treatment had $\sim 573.5 \mathrm{n} . \mathrm{mm}^{-2}$, and the control treatment had $491.6 \mathrm{n} . \mathrm{mm}^{-2}$. In addition, there was also an increase in the adaxial stomatal density of COP and SUZ clones with an average of 112.7 in the control treatment, compared to $159.6 \mathrm{n} . \mathrm{mm}^{-2}$ in the water-stress treatment (Table 5).

For all clones, there was no significant change in other anatomical variables after water stress. Although the GG clone exhibited a thicker abaxial and adaxial epidermis compared with the other clones-a characteristic that is considered a part of the plants' defense against desiccation (James and Bell 1995) — there was no significant difference between the stress and control treatments.

\section{Discussion}

Our investigations of the behavior of $\Psi_{\mathrm{pd}}$ and $\Psi_{\mathrm{md}}$ are an evidence that Eucalyptus is a species that exhibits a high resilience to water stress, since the plants recovered 1-2 days after water stress. Warren et al. (2012a, b) observed complete recovery of $\Psi_{\mathrm{pd}} 2$ days after a severe water stress in two species of Eucalyptus. In another study comparing five species of Eucalyptus, recovery of $\Psi_{\mathrm{pd}}$ occurred 4 days after rewatering (Warren et al. 2011).

We also observed that tolerant and plastic clones exhibit different stomatal sensitivity to $D$, a signal that these clones have greater ability to adapt to water-stressed situations. The relationship between gs and $D$ provides a convenient tool for describing Eucalyptus clone sensitivity under water-stress conditions (Whotehead and Beadle 2004; Gharun et al. 2015).

GABA levels increased by a factor of 0.1-10.6 after water stress of the Eucalyptus clones evaluated, confirming previous research that indicates that GABA is a fast stresssignaling molecule. Similar to our findings, in response to drought stress, GABA levels in five species of Eucalyptus and two of Acacia leaves increased 5-16-fold (Warren et al. 2011). High and rapid GABA accumulation was also reported in the leaves of bean (Raggi 1994), turnip (Thompson et al. 1996), sesame (Bor et al. 2009), and Pinus under drought stress (De Diego et al. 2013).

Studies have reported that the relationship between GABA concentration and stress is able to directly protect or promote other benefits in leaves, thereby increasing stress tolerance ( $\mathrm{Li}$ et al. 2017). Schaberg et al. (2011) associated the increase in GABA concentration with increased tolerance to cold stress in red spruce trees (Picea rubens). Moreover, a study of Arabidopsis thaliana suggests that GABA helps plants to survive stress (Bouché and Fromm 2004), while Hatmi et al. (2015) found higher GABA concentration in a drought-resistant grapevine genotype than in a sensitive variety. However, there are studies that show that the role of GABA under stress conditions is more related to stress perception than to protection, because growth was limited under stress conditions when GABA levels increased (Bor et al. 2009).

Analysis of anatomical changes after water stress showed that there was a significant reduction of leaf thickness (LT) and an increase of abaxial stomatal density in all clones after water stress. Many abiotic stresses (such as drought and high temperatures) cause water reduction in cells and consequent reduction of leaf thickness (Bussotti et al. 2002). Chartzoulakis et al. (2002) observed an LT reduction after water stress in two avocado cultivars, which was attributed to the reduction of mesophyll cell size. Cell size is related to cell wall elasticity; in general, bulk 
Table 5 Anatomical measurements in cross sections of fully expanded leaves of eight Eucalyptus clones under control and water-stress conditions

\begin{tabular}{|c|c|c|c|c|c|c|c|c|}
\hline Clone & $\begin{array}{l}\text { Abaxial } \\
\text { epiderm } \\
\text { thickness } \\
\left(10^{-2} \mu \mathrm{m}\right)\end{array}$ & $\begin{array}{l}\text { Adaxial } \\
\text { epiderm } \\
\text { thickness } \\
\left(10^{-2} \mu \mathrm{m}\right)\end{array}$ & $\begin{array}{l}\text { Palisade } \\
\text { parenchyma } \\
\left(10^{-2} \mu \mathrm{m}\right)\end{array}$ & $\begin{array}{l}\text { Spongy } \\
\text { parenchyma } \\
\left(10^{-1} \mu \mathrm{m}\right)\end{array}$ & $\begin{array}{l}\text { Homogeneous } \\
\text { parenchyma } \\
\left(10^{-1} \mu \mathrm{m}\right)\end{array}$ & $\begin{array}{l}\text { Leaf } \\
\text { thickness } \\
\left(10^{-1} \mu \mathrm{m}\right)\end{array}$ & $\begin{array}{l}\text { Abaxial } \\
\text { stomatal density } \\
\left(10^{-1} \mathrm{n} \mathrm{mm}^{-2}\right)\end{array}$ & $\begin{array}{l}\text { Adaxial } \\
\text { stomatal density } \\
\left(10^{-1} \mathrm{n} \mathrm{mm}^{-2}\right)\end{array}$ \\
\hline $\mathrm{CNB}$ & $1.57 \mathrm{ab}$ & $1.38 \mathrm{a}$ & $6.55 \mathrm{a}$ & $1.32 \mathrm{ab}$ & ND & $2.27 \mathrm{a}$ & $678.68 \mathrm{a}$ & ND \\
\hline $\mathrm{COP}$ & $1.47 \mathrm{~b}$ & $1.30 \mathrm{a}$ & ND & ND & $2.04 \mathrm{a}$ & $2.32 \mathrm{a}$ & $413.77 \mathrm{~d}$ & $169.17 \mathrm{a}$ \\
\hline FIB & $1.63 \mathrm{ab}$ & $1.25 \mathrm{a}$ & $6.92 \mathrm{a}$ & $1.33 \mathrm{ab}$ & ND & $2.31 \mathrm{a}$ & $560.43 \mathrm{abcd}$ & ND \\
\hline GG & $1.85 \mathrm{a}$ & $1.45 \mathrm{a}$ & $7.13 \mathrm{a}$ & $1.21 \mathrm{~b}$ & ND & $2.25 \mathrm{a}$ & $462.09 \mathrm{~cd}$ & ND \\
\hline JAR & $1.43 \mathrm{~b}$ & $1.18 \mathrm{a}$ & $6.58 \mathrm{a}$ & $1.30 \mathrm{ab}$ & ND & $2.22 \mathrm{a}$ & $482.51 \mathrm{bcd}$ & ND \\
\hline SUZ & $1.45 b$ & $1.28 \mathrm{a}$ & ND & ND & $1.91 \mathrm{a}$ & $2.19 \mathrm{a}$ & $443.72 d$ & $103.15 b$ \\
\hline VER & $1.55 \mathrm{ab}$ & $1.30 \mathrm{a}$ & $6.82 \mathrm{a}$ & $1.40 \mathrm{ab}$ & ND & $2.36 \mathrm{a}$ & 613.86ab & ND \\
\hline VM & $\begin{array}{l}1.57 \mathrm{ab} \\
p=0.0105\end{array}$ & $\begin{array}{l}1.30 \mathrm{a} \\
p=0.0096\end{array}$ & $\begin{array}{l}6.28 \mathrm{a} \\
p=0.3934\end{array}$ & $\begin{array}{l}1.47 \mathrm{a} \\
p=0.0568\end{array}$ & $\begin{array}{l}\text { ND } \\
p=0.1210\end{array}$ & $\begin{array}{l}2.39 \mathrm{a} \\
p=0.3357\end{array}$ & $\begin{array}{l}605.18 \mathrm{abc} \\
p<0.0001\end{array}$ & $\begin{array}{l}\text { ND } \\
p=0.0276\end{array}$ \\
\hline \multicolumn{9}{|l|}{ Treatment } \\
\hline Control & $1.60 \mathrm{a}$ & $1.32 \mathrm{a}$ & $6.89 \mathrm{a}$ & $1.37 \mathrm{a}$ & $2.00 \mathrm{a}$ & $2.34 \mathrm{a}$ & $491.57 b$ & $112.71 \mathrm{a}$ \\
\hline Stress & $\begin{array}{l}1.53 \mathrm{a} \\
p=0.1898\end{array}$ & $\begin{array}{l}1.30 \mathrm{a} \\
p=0.5125\end{array}$ & $\begin{array}{l}6.54 a \\
p=0.1525\end{array}$ & $\begin{array}{l}1.30 \mathrm{a} \\
p=0.1269\end{array}$ & $\begin{array}{l}1.96 \mathrm{a} \\
p=0.6169\end{array}$ & $\begin{array}{l}2.24 \mathrm{~b} \\
p=0.0313\end{array}$ & $\begin{array}{l}573.49 \mathrm{a} \\
p=0.0011\end{array}$ & $\begin{array}{l}159.61 \mathrm{a} \\
p=0.0927\end{array}$ \\
\hline
\end{tabular}

Means followed by the same letter do not differ statistically $(p=0.05) ; N D$ not detected

Fig. 6 Stomatal density on Eucalyptus leaves. Images of abaxial epidermis of leaf 1 before water stress (a) and leaf 2 after water stress (b)
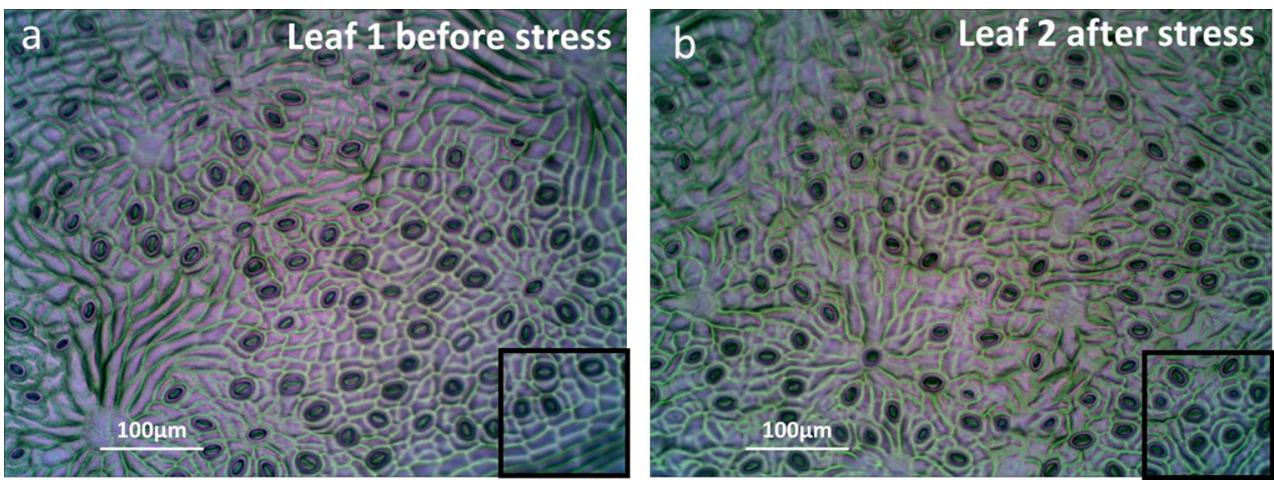

modulus of elasticity increases with cell size, and thus small cells can withstand lower pressure better than large cells (Steudle et al. 1977). This is confirmed by our results, in which mesophyll thickness decreased in stressed plants, indicating a reduction in cell size. This strategy can be considered as a drought adaptation mechanism (Cutler et al. 1977; Steudle et al. 1977).

The higher number of stomata in leaves is very common in xerophytes plants; this strategy is called "get-it-whileyou-can" and may increase their photosynthetic rates (Moore et al. 1998). Having stomata on both sides, like COP and SUZ, may increase the supply of carbon dioxide to the mesophyll cell area (Mott et al. 1982, Parkhurst 1994; Parkhurst and Mott 1990).

Higher stomatal density and smaller stomata size are forms of adaptation to drought, because these traits enable plants to regulate water transport and transpiration more effectively (Fahn and Cutler 1992; Dickison 2000; Ennajeh et al. 2010). In addition to stomatal density, stomatal behavior is very important in controlling different gas-exchange parameters. For instance, opening and closing stomata and the stomatal orientation on leaf surfaces may prove vital (Nejad et al. 2006).

Modification of stomatal density in response to drought varies between plant species and depends on the severity of water deficit. For example, a drought-induced reduction in stomata numbers was observed in Eucalyptus camaldulensis $\times$ tereticornis (Nautiyal et al. 1994), almonds (Camposeo et al. 2011), olives (Bosabalidis and Kofidis 2002), apples (Slack 1974; Elias 1995), and umbu trees (Silva et al. 2009). In contrast, increased stomatal density was observed in grass (Xu and Zhou 2008), Acacia (Craven et al. 2010), olives (Ennajeh et al. 2010), and Eucalyptus (Eksteen et al. 2013). Species that have unchanged 
stomatal characteristics in response to drought are reported for groundnuts (Clifford et al. 1995), grapes (Barbagallo et al. 1996), and olives (Gucci et al. 2002).

In summary, water stress affected multiple aspects of Eucalyptus physiology, such as water potential, stomatal control in response to water pressure deficit- $D$, and leaf anatomy. The concentration of GABA changed after drought and this occurrence allows identify the beginning and the end of critical periods of water stress. However, there was no correlation of GABA concentration and tolerance to water stress in the clones evaluated. The finding is that GABA is a fast stress-signaling molecule in Eucalyptus, but the response of gs to $D$ is a best physiological variable to differentiate drought-tolerant and drought-sensitive Eucalyptus clones.

\section{Conclusions}

In conclusion, this study has shown that:

1. All clones decreased gs with increasing $D$ in both treatments. All plastics and drought-tolerant clones (except GG) presented lower stomatal sensitivity to $D$ under stress conditions than drought-sensitive clones.

2. GABA concentrations increased fast after drought stress, but we could not find correlation with these changes and resistance to water stress.

3. All clones increased the number of stomata and reduced leaf thickness after water stress.

4. Evaluating the response of gs to $D$ is more promising than evaluating GABA concentration to differentiate drought-tolerant and drought-sensitive Eucalyptus clones.

\begin{abstract}
Author contribution statement MSGO: literature search, study design, data collection (leaf water potential, leaf gas-exchange measurements, and stomatal anatomy), data interpretation, and writing; JGF: GABA analysis (extraction and quantification); BTG and EMM: study design, data collection (leaf water potential and leaf gasexchange measurements); LAC and MA: study design, data collection (Stomatal anatomy), and data interpretation; RAM and CGBD: data analysis and data interpretation; and JLS and RFO: contributed to the idea of this work.

Acknowledgements This study was funded by Coordenação de Aperfeiçoamento de Pessoal de Nível Superior (CAPES), Forest Research Institute (IPEF) and Department of Plant Physiology and Biochemistry at University of São Paulo (USP). To the Monte Olimpo Forestry Group and Areão Farm, Laboratory of Plants Under Stress, Laboratory of Plant Morphogenesis and Reproductive Biology, and Center for Nuclear Energy in Agriculture for all analysis reported.
\end{abstract}

\section{References}

Addington RN, Mitchell RJ, Oren R, Donovan LA (2004) Stomatal sensitivity to vapor pressure deficit and its relationship to hydraulic conductance in Pinus palustris. Tree Physiol Durham 24:561-569

Alvares CA, Stape JL, Sentelhas PC, Gonçalves JLM, Sparovek G (2013) Köppen's climate classification map for Brazil. Meteorol Z Stuttgart 22:711-728

Askar A, Rubach K, Schormuller J (1972) Dunnschichtchromatographisce Trennung der in Bananen vorkommenden Amin-Fraktion. Chem Microbiol Technol Lebenshem Nürnberg $1: 187-190$

Barbagallo MG, Collesano G, Sottile I (1996) Ricerche sulla densità e sulle caratteristiche biometriche degli stomi nella vite. In: GIORNATE SCIENTIFICHE S.O.I., Erice. Erice: SOI, pp 65-66

Barger G, Dale HH (1910) A third active principle in ergot extracts. In: Proceedings of Chemical Society, London, vol 26, pp 128-129

Bor M, Seckin B, Ozgur R, Yilmaz O, Ozdemir F, Turkan I (2009) Comparative effects of drought, salt, heavy metal and heat stresses on gamma-aminobutyric acid levels of sesame (Sesamum indicum L.). Acta Physiol Plant Heidelb 31:655-659

Bosabalidis AM, Kofidis G (2002) Comparative effects of drought stress on leaf anatomy of two olive cultivars. Plant Sci 163(2):375-379

Bouché N, Fromm H (2004) GABA in plants: just a metabolite? Trends Plant Sci Camb 9(3):110-115

Bouché N, Fait A, Bouchez D, Moller S, Fromm H (2003) Mitochondrial succinic-semialdehyde dehydrogenase of the $\gamma$ aminobutyrate shunt is required to restrict levels of reactive oxygen intermediates in plants. In: Proceedings of the National Academy of Sciences of the USA, Washington, vol 100, no 11, pp 6843-6848

Bowden K, Brown BG, Batty JE (1954) 5-Hydroxytryptamine: its occurrence in cowhage. Nat Lond 174:925-926

Bown AW, Hall DE, Macgregor KB (2002) Insect footsteps on leaves stimulate the accumulation of 4-aminobutyrate and can be visualized through increased chlorophyll fluorescence and superoxide production. Plant Physiol Lanc 129:1430-1434

Breda N, Huc R, Granier A, Dreyer E (2006) Temperate forests trees and stands under severe drought: a review of ecophysiological responses, adaptation process and long-term consequences. Ann For Sci Dordr 63:625-644

Buelow W, Gisvold O (1944) A photochemical investigations of Hermidium alipes. J Am Pharm Assoc N J 33:270-274

Bussotti F, Bettini D, Grossoni P, Mansuino S, Nibbi R, Soda C, Tani C (2002) Structural and functional traits of Quercus ilex in response to water availability. Environ Exp Bot Paris 47:11-23

Buve N, Rispail N, Laine P, Cliquet JB, Ourry A, Le Deunff E (2004) Putative role of GABA as a long distance signal in up-regulation of nitrate uptake in Brassica napus L. Plant Cell Environ Malden 27:1035-1046

Camposeo S, Palasciano M, Vivaldi GA, Godini A (2011) Effect of increasing climatic water deficit on some leaf and stomatal parameters of wild and cultivated almonds under Mediterranean conditions. Scientia Horticulturae 127(3):234-241

Carroll AD, Fox GG, Laurie S, Phillips R, Ratcliffe RG, Stewart GR (1994) Ammonium assimilation and the role of gammaaminobutyric acid in $\mathrm{pH}$ homeostasis in carrot cell suspensions. Plant Physiol Lanc 106:513-520

Chartzoulakis K, Patakas A, Kofidis G, Bosabalidis A, Nastou A (2002) Water stress affects leaf anatomy, gas exchange, water 
relations and growth of two avocado cultivars. Sci Hortic B C 95:39-50

Christman MA, Richards JH, McKay JK, Stahl EA, Juenger TE, Donovan LLA (2008) Genetic variation in Arabidopsis thaliana for night-time leaf conductance. Plant Cell Environ Malden 31:1170-1178

Clifford SV, Black CR, Roberts JA, Stronach IM, Singleton-Jones PR, Mohamed AD, Azam-Ali SN (1995) The effect of elevated atmospheric $\mathrm{CO}_{2}$ and drought on stomatal frequency in groundnut (Arachis hypogaea L.). J Exp Bot 46:847-852

Craven D, Gulamhussein S, Berlyn GP (2010) Physiological and anatomical responses of Acacia koa (Gray) seedlings to varying light and drought conditions. Environ Exp Bot 69:205-213

Cutler DF, Botha T, Stevenson DW (2011) A folha. In: Cutler DF (ed) Anatomia vegetal: uma abordagem aplicada, pp 85-133

Cutler JM, Rains DW, Loomis RS (1977) The importance of cell size in the water relations of plants. Physiol Plant 40:255-260

De Diego N, Perez-Alfocea F, Cantero E, Lacuesta M, Moncalean P (2012) Physiological response to drought in radiata pine: phytohormone implication at leaf level. Tree Physiol 32:435-449

De Diego N, Sampedro MC, Barrio RJ, Saiz-Fernandez I, Moncalean P, Lacuesta M (2013) Solute accumulation and elastic modulus changes in six radiata pine breeds exposed to drought. Tree Physiol 33:69-80

Deewatthanawong R, Nock JF, Watkinsc B (2010) $\gamma$-Aminobutyric acid (GABA) accumulation in four strawberry cultivars in response to elevated $\mathrm{CO}_{2}$ storage. Postharvest Biol Technol Wash 57:92-96

Dickison WC (2000) Integrative plant anatomy. Academic Press, San Diego

Dye PJ (1996) Response of Eucalyptus grandis trees to soil water deficits. Tree Physiol Durham 16:233-238

Eksteen AB, Grzeskowiak V, Jones NB, Pammenter NW (2013) Stomatal characteristics of Eucalyptus grandis clonal hybrids in response to water stress. South For Menlo Park 75(3):105-111

Elias P (1995) Stomata density and size of apple trees growing in irrigated and non irrigated conditions. Biol Bratisl 50:115-118

Ennajeh M, Vadel AM, Cochard H, Khemira H (2010) Comparative impacts of water stress on the leaf anatomy of a drought-resistant and a drought-sensitive olive cultivar. J Hortic Sci Bangalore 85(4):289-294

Ewis AJ (1914) Acetylcoline, a new active principle of ergot. Biochem J Lond 8:44-49

Fahn A, Cutler DF (1992) Xerophytes. In: Braun HJ, Carlquist S, Ozenda P, Roth I (eds) Encyclopedia of plant anatomy. Gebruder Borntraeger, Stuttgart, pp 28-30

Fait A, Yellin A, Fromm H (2006) GABA and GHB neurotransmitters in plants and animals. In: Baluska F, Mancuso S, Volkmann $D$ (eds) Communication in plants. Rehovot, pp 171-185

FAO (2011) The state of food and agriculture, 2010-2011, Rome

Flexas J, Baron M, Bota J (2009) Photosynthesis limitations during water stress acclimation and recovery in the drought-adapted Vitis hybrid Ritcher-110 (V. berlandieri $\times V$. rupestris). J Exp Bot Lanc 60:2361-2377

Gharun M, Turnbull TL, Pfautsch S, Adams MA (2015) Stomatal structure and physiology do not explain differences in water use among montane eucalyptus. Oecol Buenos Aires 177:1171-1181

Gucci R, Grumelli A, Costagli G, Tognetti R, Monnocci A, Vitagliano C (2002) Stomatal characteristics of two olive cultivars "Frantoio" and "Leccino". Acta Hortic Leuven 586:541-544

Gulcan R, Misirli A (1990) Importance of stomata in evaluating the vigour of Prunus mahaleb rootstocks. In: XXIII Int. Hort. Congr., Firenze (Italy), 27 Aug-1 Sept 1990
Hanower P, Brzozowska J (1975) Influence d'un choc osmotique sur la composition des feuilles de cotonnier em acides amines libres. Phytochem Lond 14:1691-1694

Hatmi S, Gruau C, Trotel-Aziz P, Villaume S, Rabenoelina F, Baillieul F, Eullaffroy P, Clément C, Ferchichi A, Aziz A (2015) Drought stress tolerance in grapevine involves activation of polyamine oxidation contributing to improved immune response and low susceptibility to Botrytis cinerea. J Exp Bot Lanc 66(3):775-787

Huaman CAM (2010) Impacto do estresse abiótico em plantas no contexto das mudanças climáticas. 62 p. Tese (Livre-docência)—Faculdade de Filosofia, Ciências e Letras, Universidade de São Paulo, Ribeirão Preto

James SA, Bell T (1995) Morphology and anatomy of leaves of Eucalyptus camaldulensis clones: variation between geographically separated locations. Aust J Bot N Y 43:415-433

Kinnersley AM, Turano FJ (2000) Gamma aminobutyric acid (GABA) and plant responses to stress. Crit Rev Plant Sci Davis 19(6):479-509

Lawlor DW, Cornig G (2002) Photosynthetic carbon assimilation and associated metabolism in relation to water deficits in higher plants. Plant Cell Environ Malden 25:275-294

Li Z, Yu J, Peng Y, Huang B (2017) Metabolic pathways regulated by abscisic acid, salicylic acid and $\gamma$-aminobutyric acid in association with improved drought tolerance in creeping bentgrass (Agrostis stolonifera). Physiol Plant 159:42-58

Mac Gregor KB, Shelp BJ, PeirisS S, Bown AW (2003) Overexpression of glutamate decarboxylase in transgenic tobacco plants deters feeding by phytophagous insect larvae. J Chem Ecol Tampa 29:2177-2182

Maherali H, Johnson HB, Jackson RB (2006) Stomatal sensitivity to vapour pressure difference over a subambient to elevated $\mathrm{CO} 2$ gradient in a $\mathrm{C} 3 / \mathrm{C} 4$ grassland. Plant Cell Environ Malden 26:1297-1306

Mayer RR, Cherry JL, Rhodes D (1990) Effects of heat shock on amino acid metabolism of cowpea cells. Phytochem London 94:796-810

Mazzucotelli E, Tartari A, Cattivelli L, Foriani G (2006) Metabolism of GABA during cold acclimation and freezing and its relationship to frost tolerance in barley and wheat. J Exp Bot Lanc 57:3755-3766

MC Lean MD, Yevtushenko DP, Deschene A, Van Cauwenberghe OR, Makhmoudova A, Potter JW, Bown AW, Shelp BJ (2003) Overexpression of glutamate decarboxylase in transgenic tobacco plants confers resistance to the northern root knot nematode. Mol Breed Lleida 11:277-285

Mediavilla S, Escudeiro A (2004) Stomatal responses to drought of mature trees and seedlings of two co-occurring Mediterranean oaks. For Ecol Manag Amst 187:281-294

Mekonnen DJ, Flugge U-I, Ludewig F (2016) Gamma-aminobutyric acid depletion affects stomata closure and drought tolerance of Arabidopsis thaliana. Plant Sci 245:23-34

Michaeli S, Fromm H (2015) Closing the loop on the GABA shunt in plants: are GABA metabolism and signaling entwined? Front Plant Sci Michigan 6:1-7

Mielke MS, Oliva MA, Barros NF, Penchel RM, Martinez CA, Almeida AC (1998) Stomatal control of transpiration in the canopy of a clonal Eucalyptus grandis plantation. Trees Heidelb 13:152-160

Miranda V, Baker NR, Long SP (1981) Anatomical variation along the length of the Zea mays leaf in relation to photosynthesis. N Phytol Lanc 88:595-605

Mokotedi MEO (2013) Water relations of Eucalyptus nitens $\times$ Eucalyptus grandis: is there interclonal variation in response to experimentally imposed water stress? South For Menlo Park 75(4):213-220 
Moore R, Clark WD, Vodopich DS (1998) Botany. MsGraw Hill, Boston

Mott KA, Parkhurst DF (1991) Stomatal responses to humidity in air and helox. Plant Cell Environ Malden 14:509-515

Mott KA, Gibson AC, O'leary JW (1982) The adaptive significance of amphistomatic leaves. Plant Cell Environ Malden 5:455-460

Nautiyal S, Badola HK, Pal M, Negi DS (1994) Plant responses to water stress: changes in growth, dry matter production, stomatal frequency and leaf anatomy. Biol Plant Dordr 36(1):91-97

Nejad AR, Harbinson J, van Meeteren U (2006) Dynamics of spatial heterogeneity of stomatal closure in Tradescantia virginiana altered by growth at high relative air humidity. J Exp Bot Lanc 57:3669-3678

Ocheltree TW, Nippert JB, Prasad PVV (2013) Stomatal responses to changes in vapor pressure deficit tissue-specific differences in hydraulic conductance. Plant Cell Environ Malden 37:132-139

Oren R, Sperry JS, Katul GG, Pataki DE, Ewers BE, Phillips N, Schafer KVR (1999) Survey and synthesis of intra and interspecific variation in stomata sensitivity to vapour pressure deficit. Plant Cell Environ Malden 22:1515-1526

Parkhurst DF (1994) Diffusion of $\mathrm{CO}_{2}$ and other gases inside leaves. N Phytol Lanc 126:449-479

Parkhurst DF, Mott KA (1990) Intercellular diffusion limits to $\mathrm{CO}_{2}$ uptake in leaves. Plant Physiol Rockv 94:1024-1032

Pidgeon JD, Ober SE, Qi A, Clark JAC, Royal A, Jaggard KW (2006) Using multi-environment sugar beet variety traits to screen for drought tolerance. Field Crops Res Bonn 95:268-279

Raggi V (1994) Changes in free amino acids and osmotic adjustment in leaves of water-stressed bean. Plant Physiol Davis 91:427-434

Ramesh SA, Tyerman SD, Xu B, Bose J, Kaur S, Conn V, Domingos P, Ullah S, Wege S, Shabala S, Feijó JA, Ryan PR, Gillham M (2015) GABA signaling modulates plant growth by directly regulating the activity of plant-specific anion transporters. Nat Commun Lond 6(7978):1-7

R Core Team (2014) R: a language and environment for statistical computing. Vienna: R Foundation for Statistical Computing. Disponível em: http://www.R-project.org/. Accessed 20 Jun 2015

Rolin D, Baldet P, Just D, Chevalier C, Biran M, Raymond PNMR (2000) Study of low subcellular $\mathrm{pH}$ during the development of cherry tomato fruit. Aust J Plant Physiol Clayton South 27:61-69

Roshchina VV (2001) Neurotransmitters in plant life. Science Publishers, Moscow

Salisbury EJ (1927) On the causes and ecological significance of stomatal frequency, with special reference to the woodland flora. Philos Trans R Soc Lond Lond 216:1-65

Schaberg PG, Minocha R, Long S, Halman JM, Hawley GJ, Eagar C (2011) Calcium addition at the Hubbard Brook Experimental Forest increases the capacity for stress tolerance and carbon capture in red spruce (Picea rubens) trees during the cold season. Trees Heidelb 25:1053-1061

Schawacke R, Grallath S, Breitkreuz KE, Stransky E, Stransky H, Frommer WB, Rentsch D (1999) LeProT1, a transporter for proline, glycine betaine and gamma aminobutyric acid in tomato pollen. Plant Cell Los Angel 11:377-392

Scholander PF, Hammel HT, Bradstreet ED, Hemmingsen EA (1965) Sap pressure in vascular plants. Sci Wash 48:339-346

Scholz SS, Reichelt M, Mekonnen DW, Ludewig F, Mithofer A (2015) Insect herbivory-elicited GABA accumulation in plants is a wound-induced, direct, systemic, and jasmonate-independent defense response. Front Plant Sci 6:1128
Schulze ED, Beck E, Muller-Hohenstein K (1982) Plant ecology. Springer, Berlin

Shelp BJ, Bown AW, Mclean MD (1999) Metabolism and functions of $\gamma$-aminobutyric acid. Trends Plants Sci Camb 41:446-452

Shelp BJ, Mullen RT, Waller JC (2012) Compartmentation of GABA metabolism raises intriguing questions. Trends Plant Sci Camb 17(2):57-59

Silva EC, Nogueiral RJMC, Vale FHA, Araujo FPD, Pimenta MA (2009) Stomatal changes induced by intermittent drought in four umbu tree genotyped. Braz J Plant Physiol Campos dos Goytacazes 121:33-42

Slack EM (1974) Studies of stomatal distribution on the leaves of four apple varieties. J Hortic Sci Bangalore 49:95-103

Snedden WA, Arazi T, Fromm H, Shelp BJ (1995) Calcium/ Calmodulin activation of soybean glutamate decarboxylase. Plant Physiol Davis 108:543-549

Snowden CJ, Thomas B, Baxter CJ, Smith JAC, Sweetlove LJ (2015) A tonoplast Glu/Asp/GABA exchanger that affects tomato fruit amino acid composition. Plant J 81:651-660

Sperry JS, Adler FR, Campbell GS, Comstock JP (1998) Limitation of plant water use by rhizosphere and xylem conductance: results from a model. Plant Cell Environ Malden 21:347-359

Steudle E, Zimmermann U, Luttge U (1977) Effect of turgor pressure and cell size on the elasticity of plant cells. Plant Physiol Rockv $59: 285-289$

Steward FC, Thompson JF, Dent CE (1949) $\gamma$-Aminobutyric acid: a constituent of the potato tuber? Sci Wash 110:439-440

Thompson JF, Stewart CR, Morris CJ (1996) Changes in amino acid content of excised leaves during incubation. I. The effect of water content of leaves and atmospheric oxygen level. Plant Physiol Davis 41:1578-1582

Wallace W, Secor J, Schrader LE (1984) Rapid accumulation of $\gamma$ aminobutyric acid and alanine in soybean leaves in response to an abrupt transfer to lower temperature, darkness or mechanical manipulation. Plant Physiol Davis 75:170-175

Wang Y, Luo Z, Huang X, Yang K, Gao S, Du R (2014) Effect of exogenous $\gamma$-aminobutyric acid (GABA) treatment on chilling injury and antioxidant capacity in banana peel. Sci Hortic B C 168:132-137

Warren CR, Aranda I, Cano FJ (2011) Responses to water stress of gas exchange and metabolites in Eucalyptus and Acacia spp. Plant Cell Environ Malden 34:1609-1629

Warren CR, Aranda I, Cano FJ (2012a) Metabolomics demonstrates divergent responses of two Eucalyptus species to water stress. Metab N Y 8:186-200

Warren CR, Livingston NJ, Turpin DH (2012b) Metabolomics demonstrates divergent responses of two Eucalyptus species to water stress. Metab N Y 8:186-200

Whotehead D, Beadle CL (2004) Physiological regulation of productivity and water use in Eucalyptus: a review. For Ecol Manag Amst 193:113-140

Wood SN (2006) Generalized additive models: an introduction with R. Chapman and Hall, Boca Raton

$\mathrm{Xu} \mathrm{Z}$, Zhou G (2008) Responses of leaf stomata density to water status and its relationship with photosynthesis in a grass. J Exp Bot Lanc 59:3317-3325

Yu C, Zeng L, Sheng K, Chen F, Zhou T, Zheng X, Yu T (2014) $\gamma$ Aminobutyric acid induces resistance against Penicillium expansum by priming of defense responses in pear fruit. Food Chem Read 159:29-37 